症例

術後11年目に腹壁再発をみた胃癌の 1 例

京都府立医科大学第 2 外科学教室（主任：岡 隆宏教授）

(直接指導者：田中承男）

井口公雄田中承男山田貢一

土屋邦之小林雅夫 山岸久一

稲 葉 征四郎, 岡 隆 去

（著者身分：修練医）

\title{
A CASE OF GASTRIC CANCER RECCURRENCE ON THE ABDOMINAL WALL 11 YEARS AFTER RADICAL GASTRECTOMY
}

Kimio IGUCHI, Tsuguo TANAKA, Koichi YAMADA

Kuniyuki TSUCHIYA, Masao KOBAYASHI, Hisakazu YAMAGISHI

Seishiro INABA and Takahiro OKA

Second Department of Surgery, Kyoto Prefectural University of Medicine

胃癌の治療成績が向上した昨今，術後長期を経て再発をきたす（晚期再発）症例も多 く報告されるようになってきた。著者らは，11年前 [MCA] Borrmann V 型 ss $\gamma, \mathrm{n}_{1}, \mathrm{P}_{\mathbf{0}}$ ， $\mathrm{H}_{0}$, stage II 胃癌のため, 胃全摘術 $\mathrm{R}_{2}$ の根治切除を 董瘤が出現し，精查の結果，胃癌の腹壁再発で他に再発巣を認めない，極めて稀な晚期 再発例を経験した。腫瘤は剣状突起直上の前回手術創廐痕内に見られ, size は $35 \times 41 \mathrm{~mm}$ で境界不解明，弾性硬であった。CTでは，笳肉と同一densityで，浸潤性発育を呈して いた. biopsy の結果 adenocarcinoma と診断され, 諸検查では, 肝・腹膜・リンパ節・ 局所再発の所見はなく, 胃癌の腹壁再発と考えられた. CEA, ferritin, IAP 等の畽焬マー カーの変動はみられず，Vit. $\mathrm{B}_{12}$ の低下を伴ら巨赤芽球性賓血のみ認められた．腹壁腫 瘤切除および Second look operationを施行したところ, 他の再発あるいは，新たな原 発巣は認めなかった。原発巣と転移巣の組織所見は非常に酷似しており, Signet-ring cell を有する poorly differentiated adenocarcinomaであった。

晚期再発例は，草間らによると再発形式に特徵があり，残胃，肺，リンバ節の順であ り, 腹壁再発は，いまだ報告をみない，再発経路としては、リンバ行性等, 種々の説が あるが，不明である．しかし本例の再発経路は，手術時の implantationの可能性が高い と考えられる. 腫瘍增殖については, 腫場側のみならず宿主側の因子す重要と考えられ, 本例のごとく,11年を释て腫瘤として触知されるに至ったことは, implantされた癌細胞 か，しばらく arrestの状態にあり，何らかの機序で增殖優位となったのであろらと推察 される. 原発巣における間質反応は高く予後良好と考えられる症例であるが，再発時の PPD 皮席反応，PHA リン八球幼若化能からみた宿主の細胞性免疫能の低下を示唂する 所見は得られなかった。

柬引用語：胃癌, 晚期再発, 腹壁

はじめに

早期胃癌症例の增加と胃癌に対する手術々式の確立
ならびに補助療法の併用によって胃癌の手術成績は, 著しく向上している。これまで 5 年生存率によって胃 
癌の治療成瞔が評価されてきたか，昨今，10年生存率 により論じられるようになってきた。これとともに， 術後晚期の再発例が多く報告されるよらになり，その 再発形式の特徽が検討されるよらになってきた。最近， 著者らは, 術後11年目に腹壁再発を認めた興味ある1例 を経験したので，文献的考察を加えて報告する，

\section{症 例}

患者：51歳，男性

主訴：腹壁腫瘤

家族歴：父親，胃涭

既往歴：11年前, Borrmann $V$ 型胃癌 $[M C A]$ のた め胃全摘術食道空腸 ROUX-Y 吻合, 䒽尾脾合併切除 を施行した， $\mathrm{R}_{\mathbf{2}}$ のリンハ節郭清を行っているので，絶 対治䈍切除が施行できたと判定した，組䅧診断は poorly differenciated adenocarcinoma $て ゙, s s \gamma, n_{1}$, $\mathrm{P}_{0}, \mathrm{H}_{0}$ ， stage II であった。補助化学療法として, 術中 MMC 10mg 及び5FU 5,000mg を投与した。

現病歴：7カ月前頃より心窝部腹壁に小指頭大の腫 瘤が出現したが，疼痛等の自覚症状が無かったため放 置していた，しかし，畽瘤が炊第に增大傾向を示して きたため受診した。食欲低下，体重減少は認めなかっ た.

入院時現症：身長 $162.5 \mathrm{~cm}$, 体重 $56 \mathrm{~kg}$, 黄疸は認め ないが，眼䀫結膜に負血を認めた．表在りンパ節は触 知せず，肛門内指診でも異常を認めなかった．腹部で は, 肝腫大，腹水，凬瘤等の異常所見を認めなかった。 腹壁腫瘤は図 1 に示すごとく剣状突起上で，前回の正 中切開による手術創の上端に位固し，住円形で扁平

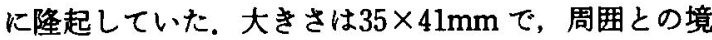
界は不鮮明，弾性硬，充実性で圧痛，可動性を認めな かった。

梌查所見：RBC $269 \times 10^{4} / \mathrm{mm}^{3}, \mathrm{Ht} 34 \%, \mathrm{Hb} 11.5$ $\mathrm{gr} / \mathrm{dl}, \mathrm{MCV} 126.2 \mu \mathrm{m}^{3}, \mathrm{MCHC} 33.8 \%$, WBC $6,300 /$ $\mathrm{mm}^{3}$, PLT $311 \times 10^{3} / \mathrm{mm}^{3}$, Vit. $B_{12} 300 \mathrm{pg} / \mathrm{dl}$, ESR $2.5 \mathrm{~mm} / \mathrm{hr}$ T.P. $6.1 \mathrm{gr} / \mathrm{dl}$, Alb. $69.6 \%, \alpha_{1} 2.5 \%, \alpha_{2}$ $8.9 \%, \beta 7.8 \%, \gamma 11.2 \%$, IgG $920 \mathrm{mg} / \mathrm{ml}$, IgM $78 \mathrm{mg} /$ $\mathrm{ml}$, IgA $190 \mathrm{mg} / \mathrm{ml}$, CRP (-), 血清 CEA 值 $2.1 \mathrm{ng} / \mathrm{ml}$, PPD 皮庙反応 $15 \times 15 \mathrm{~mm}$, PHA リンハ球幼若化率 S.I. $59.7, \mathrm{IAP}$ 值 $270 \mu \mathrm{g} / \mathrm{ml}$. 以上のごとくVit. $\mathrm{B}_{12}$ の低下 を伴 5 大赤血球性寈血以外，特に検査値に異常を認め なかった。

胸骨単純 X.P：胸骨にOsteolytic な变化は認めな かった。

上部消化管レ線およU内視鏡検查：胃全摘後食道空

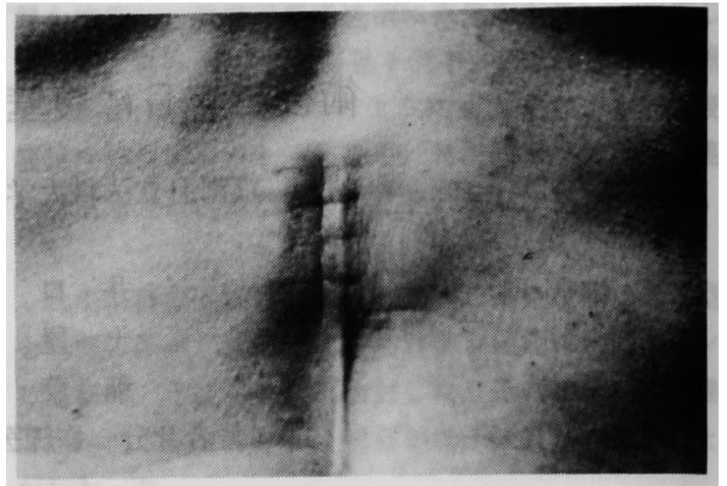

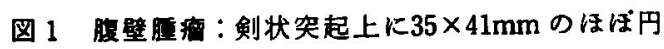
形の腫痛がみられる。

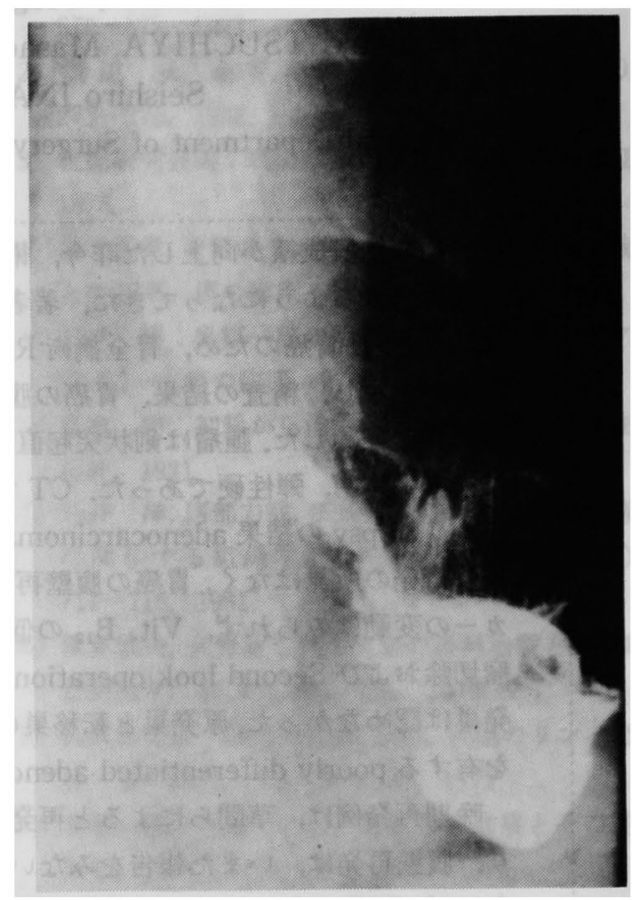

图 2 術後上部消化管透梘所見：胃全摘後食道空腸 Roux-Y物合である. 局所再発所見は認めない。

腸 Roux-Y 吻合の Ba-study は，図 2 のごとく吻合部 の通過は良好で，陰影欠損は認めなかった，内視鏡で は，食道空腸粘膜は正常で，局所再発を疑ら所見は詒 めなかった。

腹部 CT-scan 検查：肝内の SOL, 腹水, 大動脈周囲 等のリンバ節腫大は認めなかった。 困了でみられるご とく腫瘾は筋肉と同一density で，辺緑不明䀧の浸洞 性に腹壁内に発育するものと思われた。 $65 \%$ アンギオ 


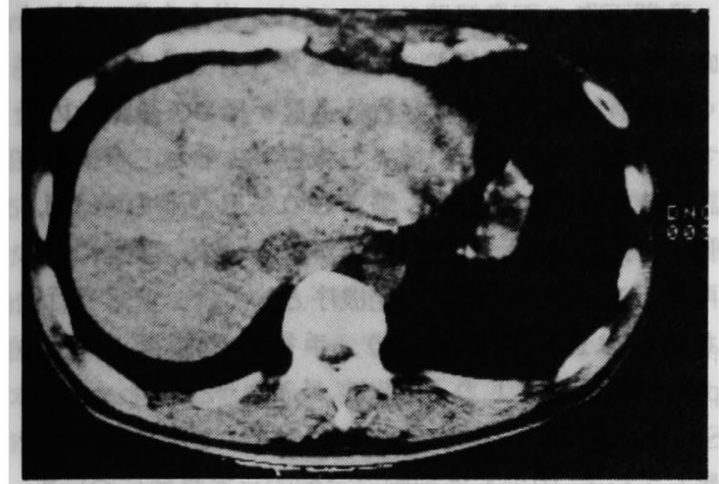

图 3 股部 CT 所見：肝にSOLを認めない,腹壁に筋 肉と同一 density の mass を認める.

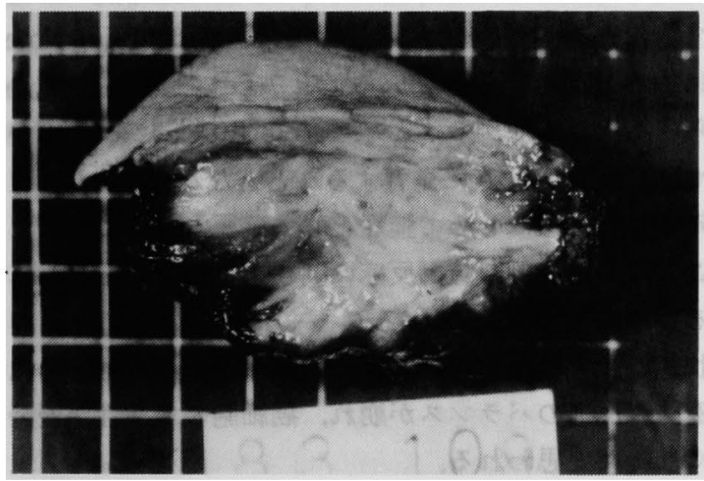

图 4 切除标本制面：灰白黄色で筋層内に浸濯し，境 界は不鮮明である。

クラフィンでは enhance されなかった.

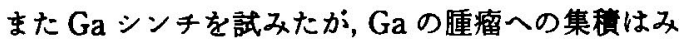
られなかった。

以上より，胃全摘後の無胃性負血および腹壁再発を 疑い, biopsyを施行したところ， adenocarcinoma と いら組織診断を得，腹壁腫瘤切除術ならびに second look operationを施行した。

手術所見：腫瘍縁より $2 \mathrm{~cm}$ 離して皮切を加え，さら に上腹部正中切開へと延長し, 開腹した. 腹腔内には, 腹水を認めず，肝・腹膜・局所再発の所見なく、リン ハ節の尰大も認められなかった。腫瘤は筋層まで浸潤 して怙り，剣状突起とともに en-block切除した。

肉眼所見：切除標本の割面を図 4 に示す. 腫瘤は, $50 \times 35 \times 24 \mathrm{~mm}$ で，灰白黄色で硬く，筋層人浸潤し， 境界不解明であった。

組所見：图 5,6に尰瘤の組織所見を示す.图 5 の こ゚とく，明るい細胞質を有する粘液産生細胞が集合し

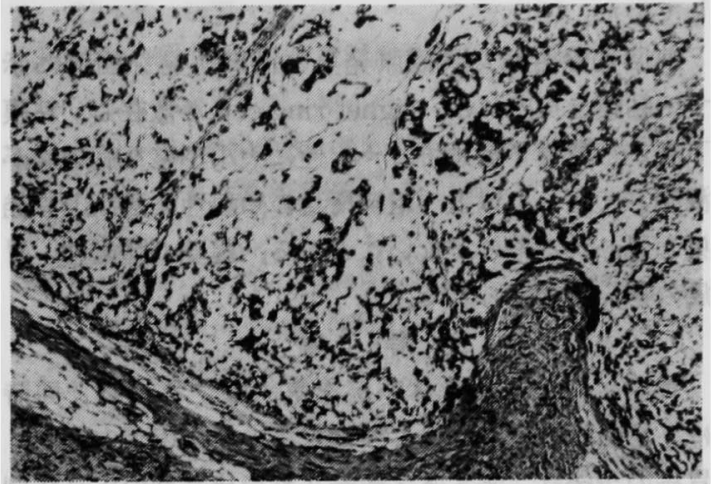

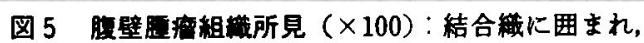
明るい細胞質を有する粘液産生細胞が集合してい る.

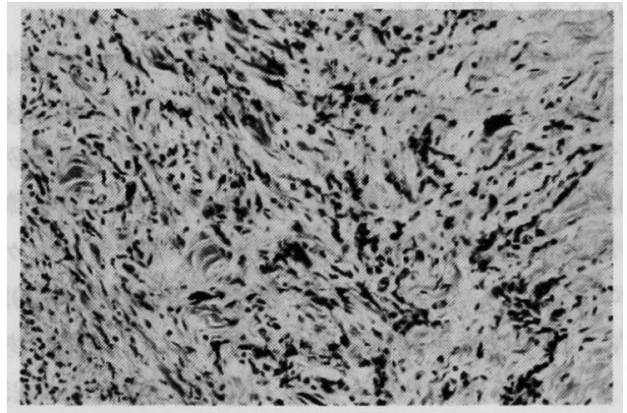

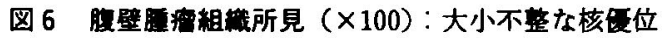
の癌細胞か，結合織中に受洞している.

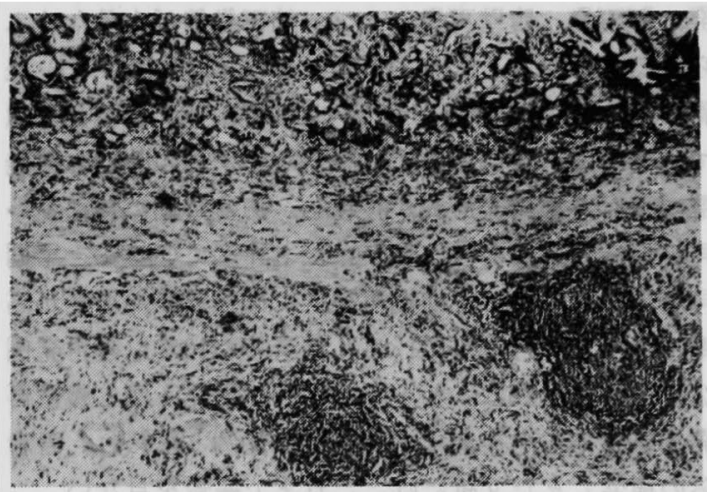

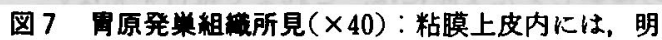
るい細胞質を有する signet-ring cell が多くみられ, 粘膜下層へは，大小不整の癌細胞がピ マン性に漫潤 している.

た muconodular carcinoma の部分と図 6 のごとく， 筑染した核優位の大小不整な細胞が浸潤している poorly differentiated adenocarcinoma の部分かi混在 
していた。

前回切除された胃癌原発坚の組織所見を图 7 に示 す. 粘膜上皮内には, signet-ring cell が散在し, 粘膜 下層から浆膜下層までビマン性に大小不整な癌細胞が 浸潤していた，以上，組織所見の類似性と臨床上原発 单と思われるるのがないことから，腹壁の腫瘤は，胃 癌の再発と考学られた。

\section{考 察}

胃癌に対する治療体系が次第に確立されると同時 に，診断学の進歩により早期胃癌の発見率が向上し， 胃癌の予後は，ますます改善され術後長期の生存症例 を多くみるよらになってきた，術後 5 年あるいは10年 間 follow up していくことにより，術後長期間を経て 再発してくる症例（いわゆる晚期再発例）が，種々の 施設から多く報告されるようになってきた。

著者らの教室において，昭和 42 年か 552 年の 11 年間 に確認された胃癌再発症例は201例であり，5年以後再 発症例は11例で，全再発例の $5.5 \%, 10$ 年以後再発例は 2 例, $1.0 \%$ であった. 第27回胃癌研究会に拈ける術後 5 年以上経過啳再発した症例の検討に関するフンヶー ト'によると， 5 年以後の再発は3,419例中295例 $8.6 \%, 10$ 年以後再発例は 33 例 $1.0 \%$ とい5結果であっ た。 た, 岩永 ら ${ }^{21}$ は, 5 年以後再発230例中25例 $10.9 \%, 10$ 年以後再発 1 例 $0.4 \%$ 之報告している。

再発形式と再発までの期間との関係について, 草 間 ${ }^{31}$ は, 2 年末満再発例の再発形式としては, 腹膜再 発, 肝再発, 腹壁再発, リンバ節再発等が大差なくみ られるのに対し，5年以後再発例の再発形式は, (1) 残 胃再発, (2) 肺再発, (3) vンハ節再発, (4) 骨再発の順 であると述べている. 岩永ら゙)は，いずれの時期の再発 群でも，各種再発形式が存在し，ある時期に特に多い 再発形式というるのはなかったと述べているが，早期 再発群に比較すると晚期再発群には残胃断端再発が高 率であったと付言している．著者らの10年以後再発例 2 例の再発形式は，肺・肝血行転移再発 1 例と腹壁再 発 1 例である，後者は，特に稀な症例と思われ，著者 らの検索しえた文献には，これまで報告を見ない。

晚期再発群の生物学的特性についてみると, 岸本 5)は, Borrmann II 型, ps (-) 例特に pm 癌例，分 化型腺癌例， stage I, II 例に多い之述べている. 草間3) は, Borrmann 分類の数字が小さくなるにつれて達く 再発するむのが多くなると報告している。しかし著者 らの腹壁再発例は，Borrmann V 型, stage II，低分 化腺癌, ss $\gamma$ (すなわち ps (+)) であった.
晚期再発の再発経路については, 岸本ら"のことく 血行性か多いと報告しているすのや，岩永ら゙のごと く癌の直接漫潤とリンパ行性進展が極めて重要な因子 であるとするもの等, 種々の報告がみられ，今後の検 討を待たねばならない，著者らのごとく、リンバ節， 肺, 肝, 腹膜ないし局所再発がみられず，腹壁にのみ 再発がみられた症例の再発機序としては, リンバ行性 あるいは血行性経路より, 手術時の腹壁への im. plantationが, より可能性が高いと思われる. Southam ${ }^{5}$ は，人癌の自家移植に関して多くの業績を 残している.中でる癌細胞の定量的自家移植について, $10^{4}, 10^{5}, 10^{6}, 10^{7}, 10^{8}$ の癌細胞を incurable な患者の 皮下へ自家移植して，その takeを観察した結果より， take か $90 \%$ 以上成立するには，108個の細胞数が必要 であると述べている．また，胃癌細胞の doubling time は約 3 日と考えられていることから6)，畽場側のみか らみると，本症例のごとく再発までの期間の長いわの では，巨大な size に発育することとなる．しかし，11 年目にして，はじめて畽瘤として確認されるに至った ことは，宿主側の防御反応の関与によるるのと思われ る. 陣内ら゙が述べているごとく prolonged arrestの 状態が長年存在していたが，腫瘍の増殖性と宿主の免 疫防御反応のパランスが崩れ, 癌細胞の増殖性が優勢 になったと思われる。

原発巣における間質反応あるいはリン八節反応は, 癌の予後と相関すると言われている8。本症例の原発 巣におけるリンパ球浸潤 (lymphoid cell infiltration （L.I.）は，图 8 のごとく高度であった。しかし、リン 八節反応の grade は, sinus histiocytosis (S.H.) 1.05, follicular hyperplasia (F.H.) 2.32, lymphoid cell

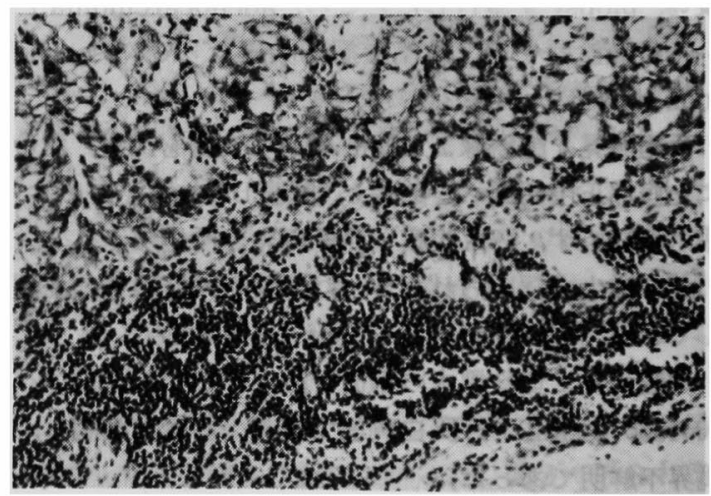

图8 胃原発巣組戗所見 $(\times 100)$ : 非常に多くのリン ・球が浸潤している. 
reaction (L.R.) 1.95と小玉ら"が，これまで報告して きた grade 分類と比較して，高度とは言い難かった。 また，再発時の非特異的紐胞性免废能についてみると， PPD $15 \times 15 \mathrm{~mm}$, PHA によるリン八球幼若化能 S.I. 59.7 免疫能の低下を示唆する所見は得られなかっ た。また，IAP 値る $270 \mu \mathrm{g} / \mathrm{ml}$ (石田 ${ }^{10)}$ によると $500 \mu \mathrm{g} /$ $\mathrm{ml}$ 以下正常)であった. 初回手術時および術後の経時 的な免疫ハラメーターの測定がなされていないので, 本症例における免疫能の変動之再発之の関保について は，明らかにされなかった。

\section{まとめ}

以上，著者らの経験した腹壁再発症例は，晚期再発 群としては，再発形式が極めて稀であり，手術時の腹 壁への implantationが, その機序として最も考えやす い. Tumor-Host Responseの関与があり，長期間 arrest の状態にあったものが，何らかの機序で増大㑯 向を示したものと考えられた。

\section{文献}

1）第27回胃癌研究会：術後 5 年以上経過後再発した 症例の検討，日癌治会誌，13：578-590，1978.

2) 岩永 㓮, 田中 元, 小山博記他: 胃癌晚期再発例 の娭討一外科臨床の立場からー，胃之腸，12：
21-31, 1977.

3）草間 悟：胃密の再発時期を左右する諸因子につ いて，胃之腸，12：61-71，1977.

4）岩本宏之, 飯塚保夫, 田中公晴他：術後 5 年以後に 再発した胃瘦症例の検討，胃之腸，12:11-19, 1977.

5) Southam, C.M.: Evidence of immunological reactions to autochthonous cancer in man. Europ. J. Cancer, 1: 173-181, 1965.

6) Clarkson, B., Ota, K., Ohkita, T., et al.: Kinetics of proliferation of cancer cell in neoplastic effusions in man. Cancer, $18: 1189-1213$, 1965.

7) 陣内侮之助, 森 武貞：癌の治等と再発一外科の 立場から一。第31回日本癌学会総会記事, S-4, 1972.

9）小玉正智, 藤田政良, 田中承男他：胃癌の宿主側に おける予後因子の検討, 癌の臨床, $22 ： 826-833$, 1976.

10）石田名香婎，田村啓二，柴田芳実：免度抑制酸性蛋 白の性状と癌患者における検出意鸢，医のあゆみ， $115: 423-433,1980$. 